\title{
HUBUNGAN STATUS PARITAS DENGAN TINGKAT KEMANDIRIAN IBU POST PARTUM SPONTAN DALAM PERAWATAN DIRI DAN BAYI DI RS PMI BOGOR
}

\author{
Nawati $^{1}$, Farial Nurhayati ${ }^{2}$ \\ ${ }^{1,2}$ Program Studi Keperawatan Bogor, Poltekkes Kemenkes Bandung \\ Email: nawati_sumaryadi@yahoo.co.id
}

\begin{abstract}
Relationship Parity Status with Degree of Independence of Spontaneus Post Partum Mother in Personal and Infant Care in RS PMI Bogor. Rooming-in is a nursing that postpartum mothers and babies are placed together in one room and the adjoining 24 hours a day. The independence of the mother's was affecting by age, education, type of birth and mother's past experience as the number of births. This study was cross sectional study, the aim of this study was to know the relationship status of parity with the level of independence of post partum mothers spontaneously on self-care and infant rooming-in implementation. This study were used nonrandom sampling by convenience sampling technique. Total sample were 30 post partum mothers in the PMI Bogor Hospital. The analysis showed that there was no relationship between the parity status with the level of independence of post partum mothers. Nurses are expected to improve nursing care with health education about how to care yourself and the baby to the mother post partum.
\end{abstract}

Keywords: Parity, Level of independence, Post partum mothers

\begin{abstract}
Abstrak: Hubungan Status Paritas dengan Tingkat Kemandirian Ibu Post Partum Spontan dalam Perawatan Diri dan Bayi di RS PMI Bogor. Rawat gabung adalah perawatan ibu nifas yang ditempatkan bersama bayi dalam satu ruangan dan berdampingan selama 24 jam dalam sehari. Faktor yang mempengaruhi kemandirian ibu adalah usia, pendidikan, tipe persalinan serta pengalaman masa lalu ibu seperti jumlah kelahiran. Penelitian ini merupakan penelitian cross sectional, untuk diketahuinya hubungan status paritas dengan tingkat kemandirian ibu post partum spontan tentang perawatan diri dan bayi dalam pelaksanaan rawat gabung. Penelitian ini menggunakan metode pengambilan non random sampling dengan teknik convenience sampling. Sampel adalah ibu post partum spontan yang berada di Rumah Sakit PMI Bogor. Hasil analisis menunjukkan tidak ada hubungan antara status paritas dengan tingkat kemandirian ibu post partum. Perawat diharapkan dapat meningkatkan asuhan keperawatan dengan penyuluhan kesehatan mengenai cara perawatan diri dan bayi kepada ibu post partum.
\end{abstract}

Kata kunci: Paritas, Tingkat kemandirian, Ibu post partum

Mengutip data hasil Survei Demografi Kesehatan Indonesia (SDKI) tahun 2012, Angka Kematian Ibu (AKI) di Indonesia mencapai 359 per 100.000 kelahiran hidup dan Angka Kematian Bayi (AKB) mencapai 32 per 1000 kelahiran hidup. Melengkapi hal tersebut, data laporan dari daerah yang diterima Kementerian Kesehatan RI menunjukkan bahwa jumlah ibu yang meninggal karena kehamilan dan persalinan tahun 2013 adalah sebanyak 5019 orang. Sedangkan jumlah bayi yang meninggal di Indonesia berdasarkan estimasi SDKI 2012 mencapai 160.681 anak (Kemenkes, 2014).

Kejadian "Fenomena 2/3" yaitu: 2/3 kematian bayi (umur 0-1 tahun) terjadi pada masa neonatal (BBL 0-28 hari), dan 2/3 kematian pada masa neonatal dini terjadi pada hari pertama (Kemenkes, 2013). Berdasarkan penelitian sebelumnya, di negara berkembang sekitar $70 \%$ ibu nifas tidak mendapatkan perawatan nifas (United States Agency International Development, 2007). Upaya pemerintah dalam menurunkan AKI dan AKB dengan diadakannya program Rumah Sakit Sayang Ibu, yang tidak tidak dapat dipisahkan dengan program Rumah Sakit Sayang Bayi, sehingga menjadi suatu program yaitu Rumah Sakit Sayang Ibu dan Bayi (RSSIB) (Kemenkes, 2013). Diperlukan sepuluh langkah perlindungan ibu dan bayi secara terpadu dan paripurna untuk mencapai tujuan pada program Rumah Sakit Sayang Ibu dan Bayi. Salah satu langkah perlindungan ibu dan bayi secara terpadu dan paripurna yaitu: menyelenggarakan pelayanan adekuat untuk nifas, membantu ibu menyususi yang benar dengan cara posisi dan perlekatan yang benar, 
mengajarkan ibu cara memerah ASI bagi bayi yang tidak bisa menyusu langsung dari ibu dan tidak memberikan ASI perah melalui botol, pelayanan neonatus sakit serta diselenggarakannya rawat gabung (Rooming In) (Kemenkes, 2013).

Berdasarkan teori keperawatan Self Care Deficit yang dikemukakan oleh Dorothea Orem, manusia pada dasarnya mempunyai kemampuan dalam merawat dirinya sendiri. Konsep Orem dibedakan menjadi 3 teori utama yaitu self care, self care deficit dan nursing system. Teori self care ini didasarkan pada empat konsep yaitu self care, self care agency, self care requisites dan theraupetic self care demand. Self care menunjukkan aktivitas menyeluruh dari individu secara mandiri dalam meningkatkan dan mempertahankan kehidupan serta kesejahteraan (Basford, 2006).

Self care deficit timbul ketika self care agency yang tidak adekuat dalam memenuhi kebutuhan self care. Keterbatasan individu dapat diakibatkan oleh sakit, kecelakaaan, ataupun efek dari tindakan pengobatan/perawatan. Perawat dapat membantu pasien melalui metode (helping method) yaitu melakukan atau membantu langsung, membimbing, pendidikan, member dukungan dan menyediakan lingkungan yang mendukung serta meningkatkan kemampuan pasien memenuhi self care-nya (Basford, 2006).

Orem melihat bahwa perawatan adalah pelayanan untuk menolong seseorang dalam memenuhi self carenya. Pada sistem keperawatan ini perawat menggunakan kelima cara helping metode. Setiap cara tersebut digunakan pada tiga tipe sistem pelayanan keperawatan yaitu: Perawatan total (wholly compensatory), individu belum mampu mengontrol dan memonitor lingkungan dan informasi dalam melakukan self care-nya, perawatan sebagian (partial compensatory), individu belum mampu melakukan beberapa atau sebagian dari aktivitas self care-nya dan pendidikan dan dukungan (educative ssupportif), individu hanya membutuhkan pendidikan dan dukungan lebih lanjut dalam melakukan self care (Basford, 2006).

Menurut Orem (1979) dalam Basford (2006) tingkat kemandirian terbagi atas mandiri, ketergantungan ringan, ketergantungan sedang, ketergantungan berat, atau ketergantungan total. Adapun faktor-faktor yang mempengaruhi kemandirian ibu dalam melakukan perawatan diri dan bayi yaitu:

\section{1) Faktor masa lalu ibu}

Melalui pengalaman di masa lalu sesorang dapat belajar cara merawat diri. Apabila ibu sudah mengenal manfaat perawatan diri atau tehnik yang akan dilakukan, maka ibu akan lebih mudah dalam melakukan perawatan diri pascabersalin. Contohnya jika ibu mengetahui atau pernah melakukan perawatan payudara sebelumnya, maka akan mempengaruhi perilaku perawatan diri ibu pascabersalin. Ibu lebih mudah belajar atau melakukan perawatan tersebut.Dalam hal ini pengalaman memberikan pengaruh pada perilaku ibu untuk melakukan perawatan diri pascabersalin. Pengalaman ibu dimana ibu yang multipara akan lebih realistis dalam mengantisipasi keterbatasan fisiknya dan dapat lebih mudah beradaptasi terhadap peran dan interaksi sosialnya, dukungan dimana ibu yang mendapat dukungan dapat memperkaya kemampuan menjadi orangtua dan mengasuh anak (Bobak, 2005).

\section{2) Faktor internal ibu pasca bersalin}

Faktor internal adalah segala sesuatu yang berasal dari dalam diri sendiri. Aktivitas merawat diri akan berbeda pada setiap individu. Hal ini juga dapat dipengaruhi oleh usia, pendidikan, karakter, keadaan kesehatan, kebudayaan. Pada usia ibu muda perawatan pascabersalin yang dilakukan akan berbeda dengan ibu yang memiliki usia lebih dewasa dimana ibu yang berusia lebih dari 35 tahun merasa bahwa merawat bayi baru lahir melelahkan secara fisik (Bobak, 2005). Demikian juga dengan pendidikan semakin tinggi pendidikan ibu, maka kepeduliannya terhadap perawatan diri semakin baik (Bobak, 2005). Kondisi fisik ibu setelah melahirkan dimana semakin cepat kesehatan ibu pulih setelah melahirkan, semakin menyenangkan sikapnya terhadap bayi dan ibu semakin yakin akan kemampuannya untuk melaksanakan peran ibu secara memuaskan (Saleha, 2009).

3) Faktor lingkungan ibu pasca bersalin

Lingkungan akan terus berubah, jika memasuki suatu fase kehidupan yang baru akan selalu terjadi penyesuaian diri dengan lingkungan. Situasi ini dapat mempengaruhi ibu dalam melakukan perawatan diri pasca bersalin. Keluarga berperan sebagai sistem pendukung yang kuat bagi anggota-anggotanya, khususnya dalam penanganan masalah kesehatan keluarga. Seperti halnya ibu pasca bersalin, maka anggota keluarga yang lain akan berusaha untuk membantu memulihkan kondisi kesehatannya ke kondisi semula. Fungsi keluarga dalam masalah kesehatan meliputi reproduksi, upaya 
membesarkan anak, nutrisi, pemeliharaan kesehatan, rekreasi dan memberi dukungan dimana ibu yang mendapat dukungan dapat memperkaya kemampuan menjadi orangtua dan mengasuh anak (Bobak, 2005).

\section{4) Petugas kesehatan}

Petugas kesehatan, khususnya perawat sangat berperan penting dalam mempengaruhi perilaku perawatan diri ibu pasca bersalin.Perawat merupakan orang yang dalam melakukan tindakannya didasari pada ilmu pengetahuan serta memiliki keterampilan yang jelas dalam keahliannya. Selain itu perawat juga mempunyai kewenangan dan tanggung jawab dalam tindakan yang berorientasi pada pelayanan melalui pemberian asuhan keperawatan kepada individu, kelompok, atau keluarga. Pemberian asuhan keperawatan ini dapat dilakukan perawat dengan memperhatikan kebutuhan dasar pasien.Di rumah sakit perawat adalah orang yang paling dekat dengan pasien, oleh sebab itu perawat harus mengetahui kebutuhan pasiennya. Perawat dapat memberikan asuhan keperawatan misalnya mengajarkan pada ibu postpartum bagaimana cara melakukan perawatan diri. Awalnya perawat dapat membantu ibu dalam melakukan perawatan diri pascasalin, kemudian anjurkan ibu untuk mengulanginya secara rutin dengan bantuan suami atau keluarga selanjutnya ibu akan mampu melakukan perawatan diri pascasalin secara mandiri (Hidayat 2004: Safarina, 2012).

\section{METODE PENELITIAN}

Penelitian ini menggunakan metode cross sectional yang dilaksanakan di RS PMI Kota Bogor pada tahun 2015. Sampel penelitian menggunakan metode pengambilan non random sampling dengan teknik convenience sampling. Jumlah pasien yang menjadi responden yaitu 30 orang. Pengumpulan data dilakukan dengan kuesioner Kuesioner tingkat kemandirian terdiri dari dari 14 butir pernyataan dimana 8 pernyataan untuk perawatan diri ibu dan 6 pernyataan untuk perawatan bayi. Analisa data menggunakan analisis univariat dan bivariat menggunakan $C h i$ square.

\section{HASIL}

\section{Distribusi Frekuensi Responden berdasarkan Karakteristik}

Hasil analisis menunjukkan bahwa mayoritas responden berusia 20-35 tahun yaitu sebanyak 27 orang (90\%). Sebagian besar responden memiliki pekerjaan yaitu 21 orang $(70 \%)$. Lebih dari setengah responden berpendidikan Sekolah Menengah Atas (SMA) yaitu 16 orang (53\%). Lebih dari setengah memiliki status paritas multipara yaitu 17 orang $(56,7 \%)$.

Tabel 1. Distribusi Frekuensi Responden berdasarkan Karakteristik

\begin{tabular}{llrr}
\hline Karakteristik & Sub karakteristik & n & \% \\
\hline Umur & 20-35 tahun & 27 & 90,0 \\
& $>35$ tahun & 3 & 10,0 \\
\hline Pekerjaan & Bekerja & 21 & 70,0 \\
& Tidak bekerja & 9 & 30,0 \\
\hline Pendidikan & SD & 2 & 7,0 \\
& SMP & 6 & 20,0 \\
& SMA & 16 & 53,0 \\
& Perguruan Tinggi & 6 & 20,0 \\
\hline Paritas & Primipara & 13 & 43,3 \\
& Multipara & 17 & 56,7 \\
\hline
\end{tabular}

2. Distribusi Frekuensi Responden Berdasarkan Tingkat Kemandirian

Tabel 2. Distribusi Frekuensi Responden berdasarkan Tingkat Kemandirian

\begin{tabular}{llrc}
\hline $\begin{array}{l}\text { Variabel/ } \\
\text { Sub Variabel }\end{array}$ & Kategori & n & \% \\
\hline $\begin{array}{l}\text { Tingkat } \\
\text { Ketergantungan }\end{array}$ & $\begin{array}{l}\text { 1. Ketergantungan } \\
\text { Ringan }\end{array}$ & 4 & 13,3 \\
& 2. Mandiri & 26 & 86,7 \\
\hline
\end{tabular}

Hasil analisis menunjukkan bahwa mayoritas resonden yaitu 26 orang $(86,7 \%)$ memiliki tingkat kemandirian mandiri.

\section{Distribusi Rerata Kemandirian Responden Dalam Perawatan Diri Terhadap Seluruh Pernyataan}

Sebagian besar (64\%) ibu mandiri dalam perawatan diri, hampir setengahnya (31\%) ketergantungan ringan, sebagian kecil (4\%) ketergantungan sedang dan sebagian kecil (1\%) ketergantungan total. 
Tabel 3. Distribusi Rerata Kemandirian Responden dalam Perawatan Diri terhadap Seluruh Pernyataan

\begin{tabular}{llllll}
\hline & $\begin{array}{l}\text { Man- } \\
\text { diri } \\
(\boldsymbol{\%})\end{array}$ & $\begin{array}{l}\text { Ketergan- } \\
\text { tungan } \\
\text { Ringan } \\
(\boldsymbol{\%})\end{array}$ & $\begin{array}{l}\text { Ketergan- } \\
\text { tungan } \\
\text { Sedang } \\
(\boldsymbol{\%})\end{array}$ & $\begin{array}{l}\text { Ketergan- } \\
\text { tungan } \\
\text { Total } \\
(\boldsymbol{\%})\end{array}$ & \\
\hline Perinium & 63 & 30 & 7 & 0 \\
Payudara & 57 & 37 & 3 & 3 \\
Ambulasi & 23 & 63 & 13 & 0 \\
BAB & 83 & 13 & 3 & 0 \\
BAK & 87 & 10 & 3 & 0 \\
Mandi & 73 & 20 & 3 & 3 \\
Berpakaian & 70 & 30 & 0 & 0 \\
Nutrisi & 57 & 43 & 0 & 0 \\
Rata-rata & 64 & 31 & 4 & \\
\hline
\end{tabular}

\section{Hubungan Status Paritas dengan Tingkat Kemandirian Responden Ibu Postpartum}

Tabel 4. Hubungan status paritas dengan Tingkat kemandirian responden Ibu postpartum

\begin{tabular}{lccccc}
\hline Status & \multicolumn{2}{c}{ Tingkat kemandirian } & \multirow{2}{*}{$\begin{array}{c}\text { P- } \\
\text { Paritas }\end{array}$} & $\begin{array}{l}\text { Ketergantungan } \\
\text { Ringan }\end{array}$ & \multicolumn{2}{c}{ Mandiri } & \\
& $\mathrm{n}$ & $\%$ & $\mathrm{n}$ & $\%$ & \\
\cline { 2 - 5 } & $\mathrm{n}$ & 50,0 & 11 & 42,3 & \multirow{2}{*}{0.773} \\
\hline Primipara & 2 & 50,0 & 15 & 57,7 & \\
Multipara & 2 & 5 & & & \\
\hline
\end{tabular}

Hasil analisis menunjukkan bahwa tidak ada hubungan antara status paritas dengan tingkat kemandirian ibu post partum.

\section{PEMBAHASAN}

Usia merupakan salah satu faktor yang mempengaruhi kesiapan fisik dan mental seseorang dalam menghadapi masalah. Pada usia ibu muda perawatan pascabersalin yang dilakukan akan berbeda dengan ibu yang memiliki usia lebih dewasa dimana ibu yang berusia lebih dari 35 tahun merasa bahwa merawat bayi baru lahir melelahkan secara fisik (Bobak, 2005). Faktor-faktor yang mempengaruhi seseorang untuk melakukan sesuatu diantaranya adalah tingkat pendidikan dan pekerjaan, dimana tingkat pendidikan yang lebih baik dapat mendorong seseorang untuk mendapatkan atau bersedia untuk melakukan sesuatu demi mencapai tujuan yang diharapkan. Pendidikan dapat mempengaruhi seseorang termasuk juga perilaku seseorang akan pola hidup terutama dalam memotivasi untuk sikap peran serta dalam perkembangan kesehatan menurut Handayani (2009) dalam Ester (2010). Multipara akan lebih realistis dalam mengantisipasi keterbatasan fisiknya dan dapat lebih mudah beradaptasi terhadap perannya
Primipara mungkin memerlukan dukungan yang lebih besar dan tindak lanjut yang mencakup rujukan ke badan bantuan dalam masyarakat (Bobak, 2005).

Di antara 500 ibu yang datang ke ke pusatpusat kesehatan, 64 (12,8\%), $396(79,2 \%)$ dan 40 $(8,0 \%)$ kasus memiliki tingkat pengetahuan rendah, sedang dan tinggi. Mayoritas ibu memiliki pengetahuan yang sedang tentang empat dimensi kesehatan masyarakat, menyusui dan gizi, metode kontrasepsi dan perawatan bayi. Subyek memiliki tingkat tertinggi dan terendah tentang pengetahuan kesehatan masyarakat dan metode kontrasepsi (Mirzaee, et al, 2013). Tingkat kemandirian ibu post partum tidak hanya dipengaruhi oleh status paritas, namun dapat juga dipengaruhi oleh pendidikan, pengetahuan dalam merawat diri dan bayi.

Sebagian besar responden memiliki tingkat ketergantungan mandiri. Responden telah dapat emlakukan aktivitas dalam perawatan diri seperti perawatan perineum, perawatan payudara, ambulasi, BAB, BAK, mandi, berpakaian dan kemampuan memenuhi kebutuhan nutrisi. Dari hasil penelitian juga didapat bahwa sebanyak 28 orang $(93 \%)$ ibu sudah mandiri dalam menyusui bayi. Setelah melahirkan baik sesar maupun spontan payudara akan mengeluarkan kolostrum. Ibu yang lahir spontan dapat lebih mudah mengeluarkan kolostrum. Pada ibu yang melahirkan bayi dengan cara spontan per vaginam biasanya ASI akan lebih cepat keluar, sedangkan pada ibu yang melahirkan melalui operasi sesar biasanya ASI mulai banyak keluar pada hari ke-5.

Ibu mengindikasikan bahwa untuk meningkatkan kualitas layanan lebih lanjut, penekanan yang lebih besar harus ditempatkan pada: (1) pendidikan kesehatan pada perawatan bayi; (2) alokasi waktu lebih untuk diskusi dengan petugas kesehatan selama kunjungan rumah ibu post partum sehingga pertanyaan dan keprihatinan mereka dapat diatasi secara efektif; (3) akses yang mudah ke petugas kesehatan pada saat dibutuhkan daripada menunggu kunjungan rumah resmi yang ditentukan; dan (4) penyediaan pelatihan yang berkesinambungan bagi pemberi pelayanan kesehatan ibu dan anak. Temuan akan relevan untuk tenaga kesehatan dan pembuat kebijakan yang terlibat dalam perencanaan dan pelaksanaan pelayanan kesehatan ibu dan anak di daerah perkotaan yang sama di negara-negara berkembang (Lomoro et al, 2002). 


\section{SIMPULAN}

Dari hasil penelitian ini maka dapat disimpulkan bahwa tidak ada hubungan antara status paritas dengan tingkat kemandirian ibu post partum.

\section{DAFTAR PUSTAKA}

Basford, Lynn \& Slevin, Oliver. (2006). Teori dan Praktek Keperawatan Pendekatan Integral Pada Asuhan Pasien. Jakarta: EGC.

Bobak, Lowdermilk, Jensen. 2005. Buku Ajar Keperawatan Maternitas. Edisi 4. Jakarta: EGC.

Khadijeh Mirzaee, Somayyeh oladi ghadikolaee, Mohamad Taghi Shakeri' Seyed mojtaba mousavi Bazzaz. 2013. Maternal Knowledge on Postpartum Care in Healthcare Centers of Mashhad, Iran in 2013. Journal of Midwifery and Reproductive Health. http://jmrh.mums.ac.ir/article_4810_b5dd d632b476bf4187ff23856160e577.pdf (Diakses pada Maret 2015).

Kementerian Kesehatan RI. 2014. Jadilah Kartini Indonesia yang Tidak Mati Muda (Pencanangan Kampanye Peduli Kesehatan Ibu 2014). http://www.depkes.go.id/article/print/2014

\section{SARAN}

Perawat

diharapkan

dapat meningkatkan asuhan keperawatan dengan penyuluhan kesehatan mengenai cara perawatan diri dan bayi kepada ibu post partum.

04300001/jadilah-kartini-indonesia-yangtidak-mati-muda-pencanangan-kampanyepeduli-kesehatan-ibu-2014.html (Diakses pada 29 Maret 2015).

2013. Standar Pelayanan Keperawatan Rumah Sakit Ibu dan Anak. Jakarta: Tidak dipublikasikan. . 2013. Pedoman

Penyelenggara Rumah Sakit Sayang Ibu dan Bayi. Jakarta: tidak dipublikasikan.

O. A. Lomoro, J. E. Ehiri, X. Qian, S. L. Tang. 2002. Mothers' perspectives on the quality of postpartum care in Central Shanghai, China. International Journal for Quality in Health Care.

United States Agency International Development. 2007. Family Planning for Women During the Postpartum Period: A community Approach.

America. http://www.esdproj.org/ (Diakses pada 08 Februari 2015). 